\title{
Erratum: Interfering amino terminal peptides and functional implications for heteromeric gap junction formation
}

\section{Eric C. Beyer ${ }^{1}$, Xianming Lin $^{2}$ and Richard D. Veenstra ${ }^{2 *}$}

1 Department of Pediatrics, University of Chicago, Chicago, IL, USA

2 Department of Pharmacology, SUNY Upstate Medical University, Syracuse, NY, USA

*Correspondence: veenstr@@upstate.edu

Edited by:

Harry Fozzard, The University of Chicago, USA

\section{A commentary on}

Interfering amino terminal peptides and functional implications for heteromeric gap junction formation

by Beyer, E. C., Lin, X., and Veenstra, R. D. (2013). Front. Pharmacol. 4:67. doi: 10.3389/fphar.2013.00067
There was an inadvertent error in Figure 4, panel $(\mathbf{F})$, pertaining to the effect of the iNT-Cx50a peptide on the spermine block of rat $\mathrm{Cx} 40$ gap junctions. The data that originally appeared in this figure was the same data plotted in Figure 4, panel (B) for the iNT$\mathrm{Cx} 40 \mathrm{~b}$ peptide. The data in Figure 4B is correct and the correct data for the iNT-Cx50a $(n=4)$ is now illustrated in this revised version of Figure 4 for the original manuscript. The corresponding author regrets the error that occurred while configuring the figures for this manuscript and accepts sole responsibility for this mistake. The iNT-Cx50a peptide
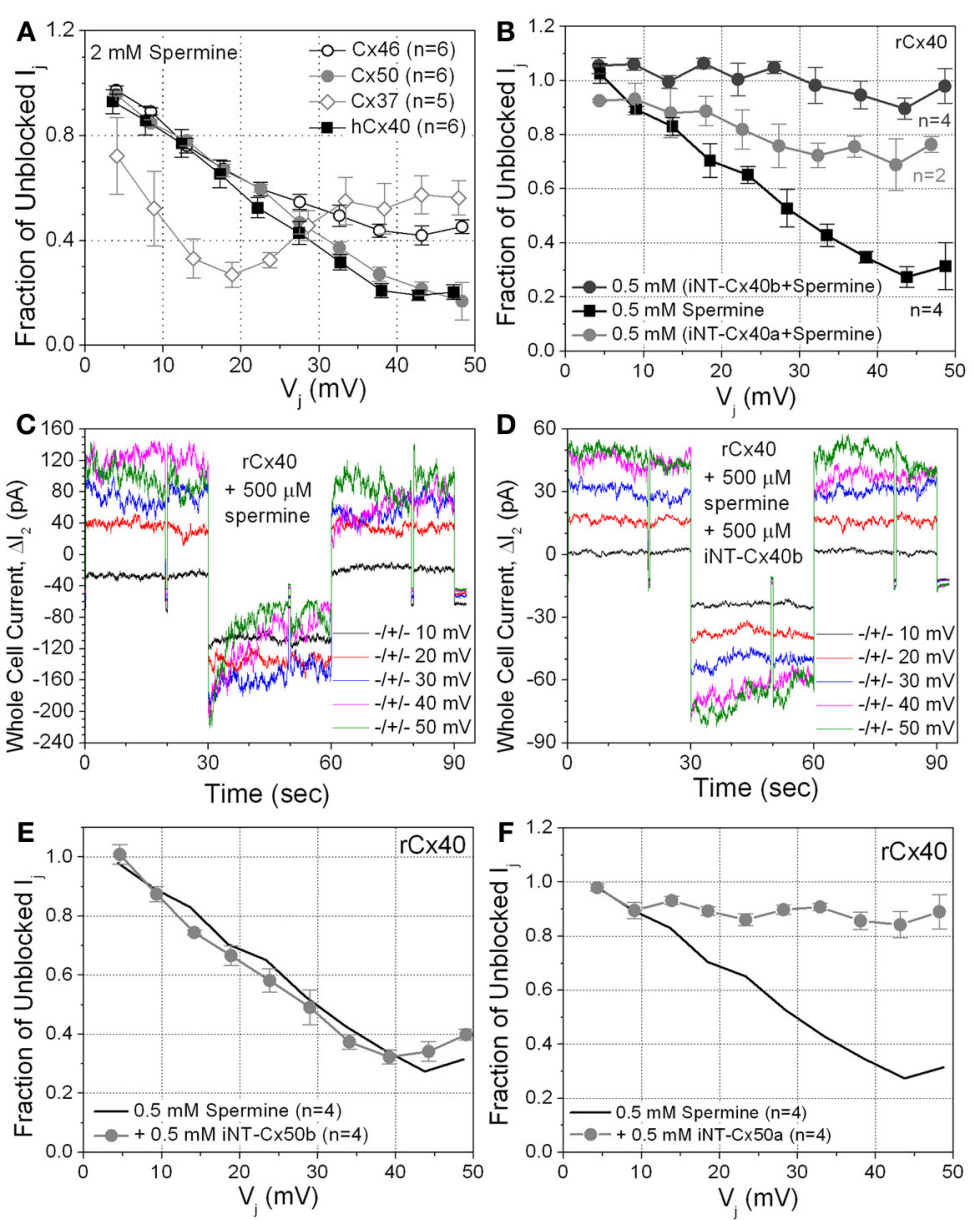

FIGURE 4 | Continued 
FIGURE 4 I (A) The sensitivity of four connexin-specific gap junctions was tested using the $2 \mathrm{mM}$ spermine block assay. Human $\mathrm{Cx40}$ (hCx40, $\mathbf{\square}$ ) displayed similar $\mathrm{V}_{\mathrm{j}}$-dependent sensitivity to spermine as $\mathrm{rC} \times 40$ despite the $\mathrm{N} 9$ substitution

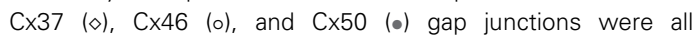
$\geq 60 \%$ inhibited by spermine. The maximum inhibition of $\mathrm{C} \times 37$ $g_{j}$ occurred at $+20 \mathrm{mV}$, half the $V_{j}$ required for maximal block of any other known connexin-specific gap junction. (B) The ability of iNT-Cx40 peptides to interfere with spermine block was tested by adding $500 \mu \mathrm{M}$ spermine and iNT-Cx40a or iNT-Cx40b peptides to one patch pipette. The carboxyl-terminal hydroxylated $(-\mathrm{OH}, z=-4)$ form of the $\mathrm{Cx} 40$ peptide (Cx40b) effectively abolished the $\mathrm{V}_{\mathrm{j}}$-dependent spermine block, while the amidated form $\left(\mathrm{C} \times 40 \mathrm{a},-\mathrm{NH}_{2}, \quad z=-3\right)$ was only partially effective (ANOVA, $f$-value $<0.05$ ). (C) $\Delta \mathrm{I}_{2}$ current traces from an $\mathrm{rCx} 40$ cell pair with $500 \mu \mathrm{M}$ spermine added to cell 1. $I_{j}$ decreased during the positive 30,40 , and $50 \mathrm{mV} V_{j}$ pulses and returned to prepulse levels during subsequent negative $V_{j}$ pulses, This illustrates the time- and $V_{j}$-dependent spermine block and unblock of $\mathrm{rCx} 40$ gap junctions. (D) $\mathrm{I}_{2}$ current traces from an $\mathrm{rC} \times 40$ cell pair experiment with $500 \mu \mathrm{M}$ spermine and the $\mathrm{iNT}-\mathrm{C} \times 40 \mathrm{~b}$ peptide added to cell 1 . Accounting for the occurrence of $V_{j}$-dependent gating at $V_{j} \geq \pm 40 \mathrm{mV}$, instantaneous and steady state $I_{2}$ increased in a stepwise (ohmic) fashion with increasing $V_{j}$ amplitude, indicative of a lack of spermine block. (E) A negatively charged $(z=-4)$ iNT-Cx50b peptide failed to significantly prevent the $500 \mu \mathrm{M}$ spermine block of rCx40 gap junctions, suggesting that the bimolecular interactions between the rCx40 NT domain, spermine, and iNT peptides are not purely based on electrostatic forces. (F) An iNT-Cx50a peptide [based on amino acids 9-13 and possessing a carboxyl-terminal valence $(z)$ of -3 ] significantly reduced the $500 \mu \mathrm{M}$ spermine block of $\mathrm{rCx} 40$ gap junctions, suggesting a structural requirement for the interactions of iNT-Cx peptides with NT domains or spermine molecules. was $95 \%$ effective in preventing the inhibition of $\mathrm{Cx} 40$ gap junctions by 500 microM spermine and inclusion of the correct data for the iNT-Cx50a peptide does not alter the results or conclusion of the original manuscript, just the accuracy of reporting the experimental data. The legend for Figure 4 is not affected in any way and is reproduced here in its entirety.

Received: 26 June 2013; accepted: 04 July 2013; published online: 23 July 2013.

Citation: Beyer EC, Lin X and Veenstra RD (2013) Erratum: Interfering amino terminal peptides and functional implications for heteromeric gap junction formation. Front. Pharmacol. 4:94. doi: 10.3389/fphar. 2013.00094
This article was submitted to Frontiers in Pharmacology of Ion Channels and Channelopathies, a specialty of Frontiers in Pharmacology.

Copyright (c) 2013 Beyer, Lin and Veenstra. This is an open-access article distributed under the terms of the Creative Commons Attribution License, which permits use, distribution and reproduction in other forums, provided the original authors and source are credited and subject to any copyright notices concerning any third-party graphics etc. 